Bangl. J. Vet. Med. (2008). 6 (2): 169-174

\title{
CHARACTERIZATION OF SALMONELLA SEROVARS IN COMPARISON WITH SOME ENTEROBACTERIA BY SDS-PAGE ANALYSIS
}

\author{
F. Begum ${ }^{1}$, Y. Adachi ${ }^{1}$ and M. S. R. Khan ${ }^{2}$ \\ ${ }^{1}$ Animal Health Laboratory, School of Agriculture, Ibaraki University, Chuou, Ami, Ibaraki 300-0393, Japan \\ ${ }^{2}$ Department of Microbiology and Hygiene, Faculty of Veterinary Science, Bangladesh Agricultural University, \\ Mymensingh-2202, Bangladesh
}

\begin{abstract}
Salmonella bacteria causes a wide variety of disease and disease syndrome in different animals, birds including human beings and remains as a serious problem with public health significance throughout the world. A suitable vaccine or suitable immunogen detection system is not yet still available. However, it is interesting to characterize of a common immunodominant surface protein from a wide variety of Salmonella serovars to get the protective measures of Salmonellosis. Salmonella surface protein characterization could be useful for development of protective measures against Salmonellosis and for analysis of the protein profile relationship among the Salmonella serovars. A common and immunodominant surface protein of Salmonella serovars was critically important. SDS-PAGE analysis during the period of January 2004 to December 2004 showed a target surface protein of $37.81 \mathrm{kDa}$ among the 54 Salmonella serovars in comparison to some enterobactors. The protein profiles in SDS-PAGE of Salmonella serovars were not different among all Salmonella serovars examined in this study. In contrast to the protein band of $37.81 \mathrm{kDa}$ in all serovars of Salmonella were compared and recorded with those of Escherichia coli, Enterobacter aerogenes, Klebsiella pneumoniae, and Enterobacter cloacae and were detected as $36.5 \mathrm{kDa}$. SDS-PAGE analysis showed different size of protein of Salmonella serovars and other tested enterobacters. However, it needs further investigation including Western blotting and 2-D PAGE analysis of the specific band of $37.81 \mathrm{kDa}$ and $36.5 \mathrm{kDa}$ protein.
\end{abstract}

Key words: Salmonella serovars, characterization, SDS-PAGE

\section{INTRODUCTION}

Salmonella enterica (S. enterica) serovar $S$. typhi cause systemic infection and typhoid fever, whereas other serovars such as S. typhimurium cause gastroenteritis (McClelland et al., 2001). Salmonella infection in calves remains to be a major problem. Substantial economic losses were through mortality and poor growth of infected animals as well as the hazard of transmitting food poisoning to humans. Many outbreaks of Salmonella infection have been reported world wide. The most frequently isolated serovars are S. typhimurium, S. enteritidis, S. dublin, S. anatum, S. newport, S. cerro, S. montevideo and S. agona. These are considered the major hostadapted Salmonella for cattle (Mitz et al., 1981, Konrad et al., 1994, Ritchie et al., 2001 and Veling et al., 2002). SDS-PAGE of only S. typhimurium, S. enteritidis and S. dublin was conducted by Nakajima, (1999) in order to observe the suitability of the technique. But comparative analysis of protein profiles was not performed among the members of Enterobacteriaceae which possess ECA (Erbel et al., 2003, Mier and Mayer 1985). SDS-PAGE with porin proteins or OmpF, OmpC, and OmpD of S. typhimurium was reported by Sing et al. (1995, 1992). SDS-PAGE of S. typhimurium (Udhayakumar and Muthukkaruppan, 1987), S. typhi (Tabaraie et al., 1994), S. typhimurium LT2 (Matsue and Arai, 1989), and S. typhimurium SH5014 (Kuusi et al., 1979) were also reported. However, these studies with the limited number of serovars did not give a conclusive idea regarding a common vaccine candidate against infections of a wide variety of Salmonella serovars.

Therefore, in the present study, SDS-PAGE of a wide variety of 54 Salmonella serovars was performed and compared with that of several Enterobacteria to find out a suitable common immunodominant surface protein regarding the control of Salmonellosis.

\section{MATERIALS AND METHODS}

The whole research work was performed in the Animal Health Laboratory, School of Agriculture, Ibaraki University, Ibaraki, Japan during the period of January 2004 to December 2004. To perform this study, a total of fifty four Salmonella serovars (A 1 Agona, A 2 Albany, A 3 Amage, A 4 Anatum, A 5 Bardo, A 6 Bareily, A 7 
Blegdam, A 8 Blockley, A 9 Braenderup, A10 Brandenburg, A11 Bredeny, A12 Cerro, A13 Choleraesuis, A14 Colorado, A15 Corvalis, A16 Derby, A17 Dublin, A18 Duesseldorf, A19 Enteritidis, A20 Gaminara, A21 Give, A22 Grumpensis, A23 Hadar, A24 Havana, A25 Heidelburg, A26 Infantis, A27 Istanbul, A28 Johannesburg, A29 Kentucky, A30 Krefeld, A31 Lexington, A32 Liverpool, A33 Livingstone, A34 London, A35 Mbandaka, A36 Meleagridis, A37 Montevideo, A38 Muenchen, A39 Newport, A40 Ohio, A41 Oranienburg, A42 Orion, A43 Ouakam, A44 Panama, A45 Potsdam, A46 Rissen, A47 Sandiego, A48 Senftenberg, A49 Taksony, A50 Tennesse, A51 Thompson, L1338 Typhimurium, A53 Virchow and A54 Worthington) were obtained from the National Institute of Animal Health, Kannondai, Tsukuba, Japan and other Enterobacteria, namely Escherichia (E.) coli, Enterobacter (Ent.) aerogenes, Klebsiella (K.) pneumonia, and Ent. cloacae, were obtained from the repository of the Animal Health Laboratory, School of Agriculture, Ibaraki University, Japan.

The Culture of Salmonella serovars and Enterobacteria were prepared according to the procedure described by Hegazy and Adachi, 2000. Whole cell lysate of Salmonella serovars and Enterobacteria for SDS-PAGE analysiswas prepared from all serovars of Salmonella and Enterobacteria as described previously (Nakamura et al., 2002). The whole cell lysate protein concentration was measured according to the method of Lowry et al. (1951). Protein concentration was measured by a spectrophotometer at the wave length of $750 \mathrm{~nm}$. Optimization of protein concentration for SDS-PAGE was done through a series of experimental SDS-PAGE. Then, SDS-PAGE was carried out as previously described by Laemmli, 1970 with some modification using all fifty four Salmonella serovars and some Enterobacteria. Briefly, the sedimented cells were suspended in $100 \mu \mathrm{l}$ of physiological saline and mixed with an equal volume of dye buffer containing $0.125 \mathrm{M}$ Tris hydroxymethylamino methane, 4\% SDS, 10\% 2-mercaptoethanol, 20\% glycerol, and $0.2 \%$ bromophenol blue. After shaking vigorously by vortex, the sample was boiled for $5 \mathrm{~min}$ and then centrifuged at 15,000rpm for 5 $\min$ at $16^{\circ} \mathrm{C}$. The supernatant was taken for SDS-PAGE using a rapid analytical slab electrophoretic experiment (Atto, Japan). Condition of a separation gel for SDS-PAGE was decided by using $10 \%$ and $12 \%$ separation gels. The samples were loaded with molecular size markers (Bio-Rad, U.S.A.) and run for $3 \mathrm{~h}$ at $10 \mathrm{~mA}$. The gels after running were stained with 0.25\% Coomassie Brilliant Blue R-250 (CBB, Sigma, USA) in methanol: acetic acid: distilled water ( $5: 1: 5$ ) with gentle shaking for $20 \mathrm{~min}$ and then destained with the solution containing $5 \%$ methanol and 7.5\% acetic acid. All chemical reagents were purchased from Wako chemical Co. Ltd. Tokyo, Japan.

\section{RESULTS AND DISCUSSION}

The protein profiles of 54 Salmonella serovars were compared within the serovars and also with the some Enterobacteria (Fig.1, 2, 3, 4, 5 and 6). The suitability of the gel percentage was studied and it was shown that the over all resolution of the protein profiles including a $37.81 \mathrm{kDa}$ protein in all Salmonella serovars using the $10 \%$ separation gel became most clear and detectable (Fig. 1, 2, 3, 4, and 5) as compared with 7\% (data not shown) and $12 \%$ separation gels (Fig. 6). The purpose of this study was to identify protein profiles of a wide variety of Salmonella serovars by a suitable, reliable and common technique. The technique was SDS-PAGE which is widely used for the detection of protein. Fifty four serovars of Salmonella were subjected to well defined SDS-PAGE (Fig. 1, 2, 3, 4, and 5). The results demonstrated the presence of the common heavy protein band of $37.81 \mathrm{kDa}$ among all 54 serovars. Although SDS-PAGE profile analyses of porin protein or OmpF, OmpC, and OmpD of Salmonella typhimurium (Sing et al., 1995 and 1992, Udhayakumar and Muthukkaruppan 1987, Tabaraie et al., 1994, Matsue and Arai, 1989, and Kuusi et al., 1979) was also reported. Comparative SDS-PAGE of a wide variety of Salmonella serovars with Enterobacteria is not still available. The present findings showed that there was the common heavy protein band of $37.81 \mathrm{kDa}$ among all fifty four Salmonella serovars.

The present investigation describes the characterization of the immunodominant surface protein from a wide variety of Salmonella serovars and the study of protective potential of that particular protein in order to control Salmonellosis. The protective potential of Salmonella using an outer surface protein was studied by Tabaraei et al. (1994) Muthukkumar et al. (1993) Udhaykumar and Muthukkaruppan (1987) Matsui et al. (1989) and Kuusi et al.(1981, 1979) in mice. They used only a limited number of Salmonella (S. typhi and S. typhimurium) strains. Moreover, the previous investigators focused on the outer membrane proteins of $S$. typhimurium, S. enteritidis and S. dublin which induced the strong humoral antibodies to the Salmonellae. However, Nakajima (1999) used only 3 serovars of Salmonella. 
The selected Enterobacteria were included due to the presence of ECA among the members of the family Enterobacteriacae (Erbal et al., 2003, Meier and Mayer, 1985, Ramos et al., 2003,). The common protein of $37.81 \mathrm{kDa}$ was found in all Salmonella serovars, while the $36.5 \mathrm{kDa}$ of Enterobacteria was found through SDSPAGE studies. Fifty four Salmonella serovars proved that the $37.81 \mathrm{kDa}$ protein of Salmonella serovars was clearly different from the $36.5 \mathrm{kDa}$ protein of Enterobacteria (Fig. 6) although there is a report of ECA present among the members of Enterobacteriacae (Erbal et al., 2003, Meier and Mayer, 1985, Ramos et al., 2003).

This is a first report for accurate comparasion of 54 Salmonella serovars with several Enterobacteria by using the well-defined SDS-PAGE.

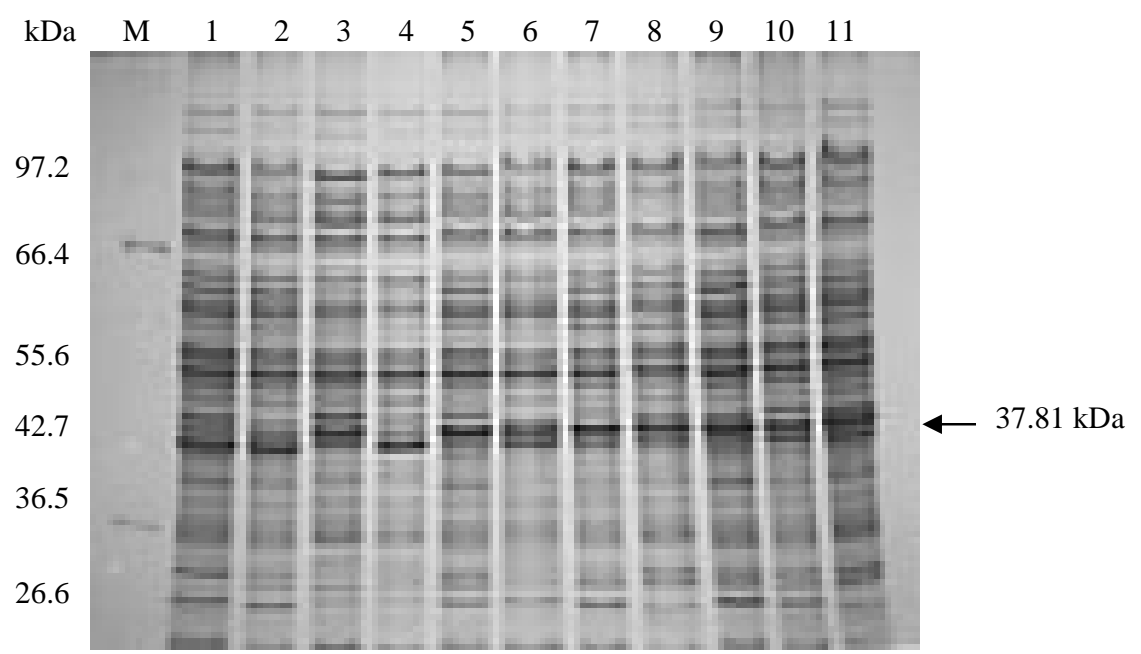

Fig. 1. Comparison of the protein profiles among Salmonella serovars. Lane 1, S. agona A1; Lane 2, S. albany A2; Lane 3, S. amager A3; Lane 4, S. anatum A4; Lane 5, S. bardo A5; Lane 6, S. bareily A6; Lane 7, S. blegdam A7; Lane 8, S. blockley A8; Lane 9, S. braenderup A9; Lane 10, S. brandenburg; Lane 11, S. bredeny A11. Arrow indicates $37.81 \mathrm{kDa}$. M, molecular size markers.

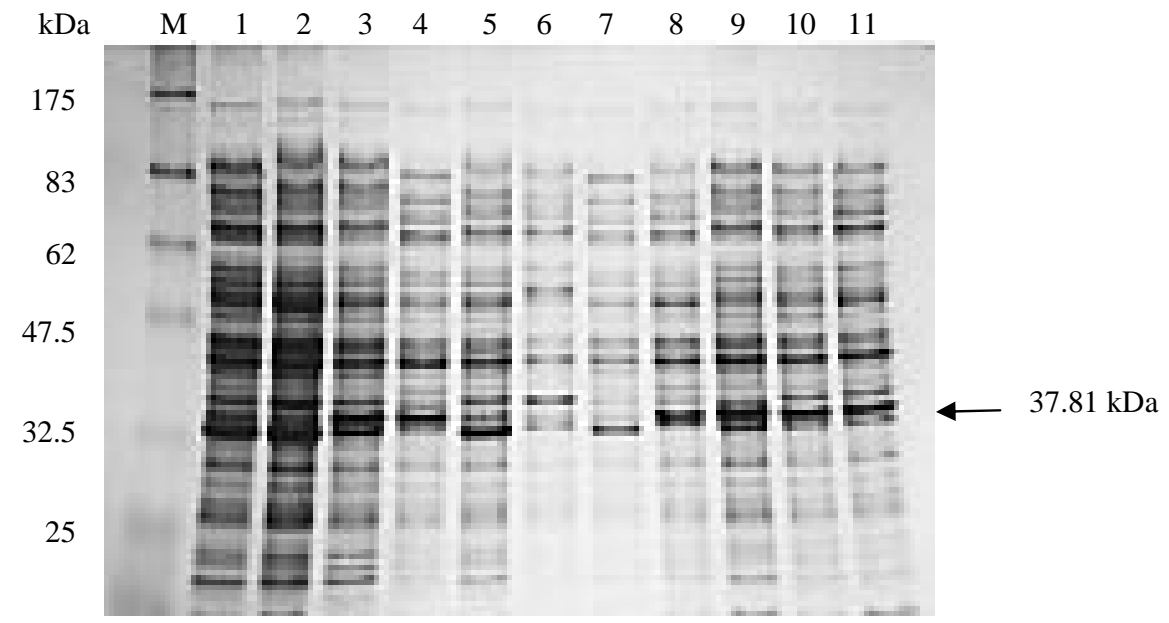

Fig. 2. Comparison of the protein profiles among Salmonella serovars. Lane 1, S. cerro A12; Lane 2, S. choleraesuis A13; Lane 3, S. colorado A14; Lane 4, S. corvalis A15; Lane 5, S. derby A16; Lane 6, S. dublin A17; Lane 7, S. duesseldorf A18; Lane 8, S. enteritidis A19; Lane 9, S. gaminara A20; Lane 10, S. give A21; Lane 11, S. grumpensis A22. Arrow indicates $37.81 \mathrm{kDa}$. M, molecular size markers. 


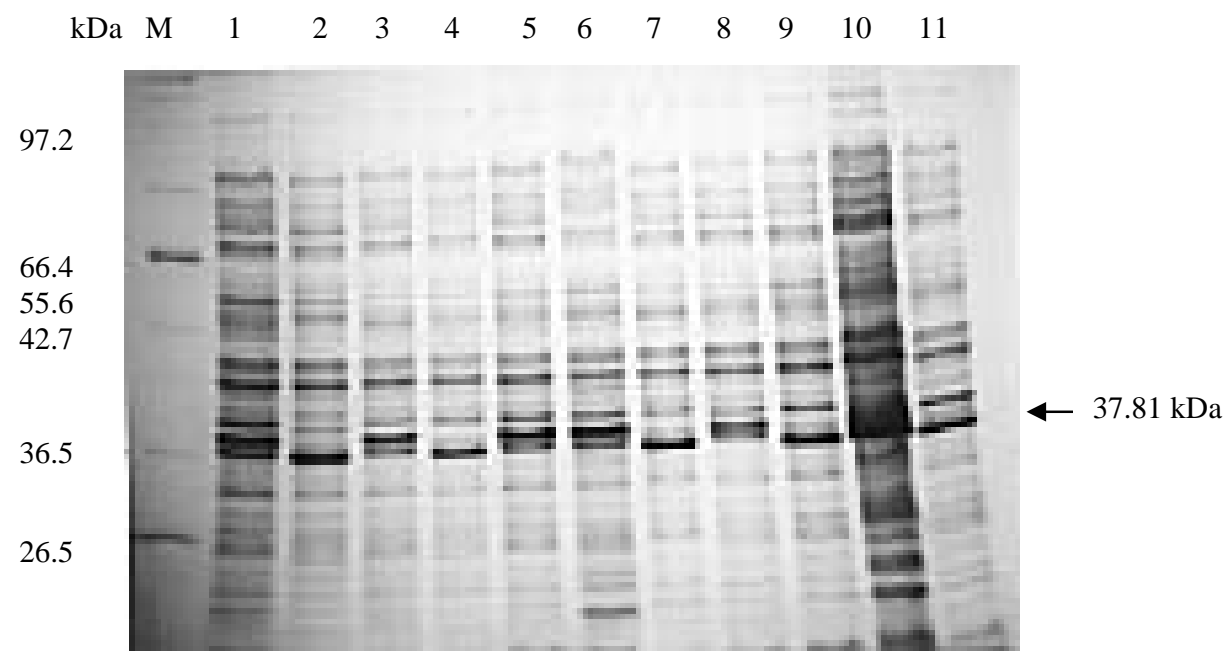

Fig. 3. Comparison of the protein profiles among Salmonella serovars. Lane 1, S. hadar A23; Lane 2, S. havana A24; Lane 3, S. heidelburg A25; Lane 4, S. infantis A26; Lane 5, S. istanbul A27; Lane 6, S. johannesburg A28; Lane 7, S. kentucky A29; Lane 8, S. krefeld A30; Lane 9, S. lexington A31; Lane 10, S. liverpool A32; Lane 11, S. livingstone A33. Arrow indicates $37.81 \mathrm{kDa}$. M, molecular size markers.

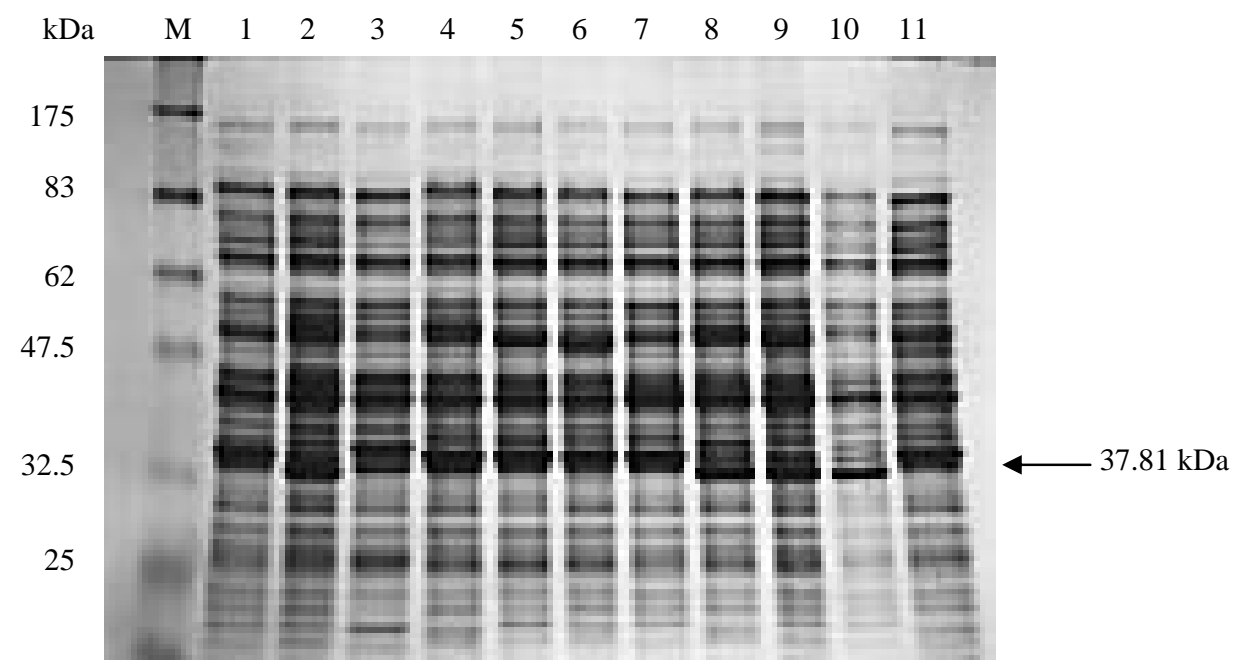

Fig. 4. Comparison of the protein profiles among Salmonella serovars. Lane 1, S. london A34; Lane 2, S. mbandaka A35; Lane 3, S. meleagridis A36; Lane 4, S. montevideo A37; Lane 5, S. muenchen A38; Lane 6, S. newport A39; Lane 7, S . ohio A40; Lane 8, S . oranienburg A41; Lane 9, S. orion A42; Lane 10, S. ouakam A43; Lane 11, S. panama A44. Arrow indicates $37.81 \mathrm{kDa}$. M, molecular size markers. 
Characterization of Salmonella serovars

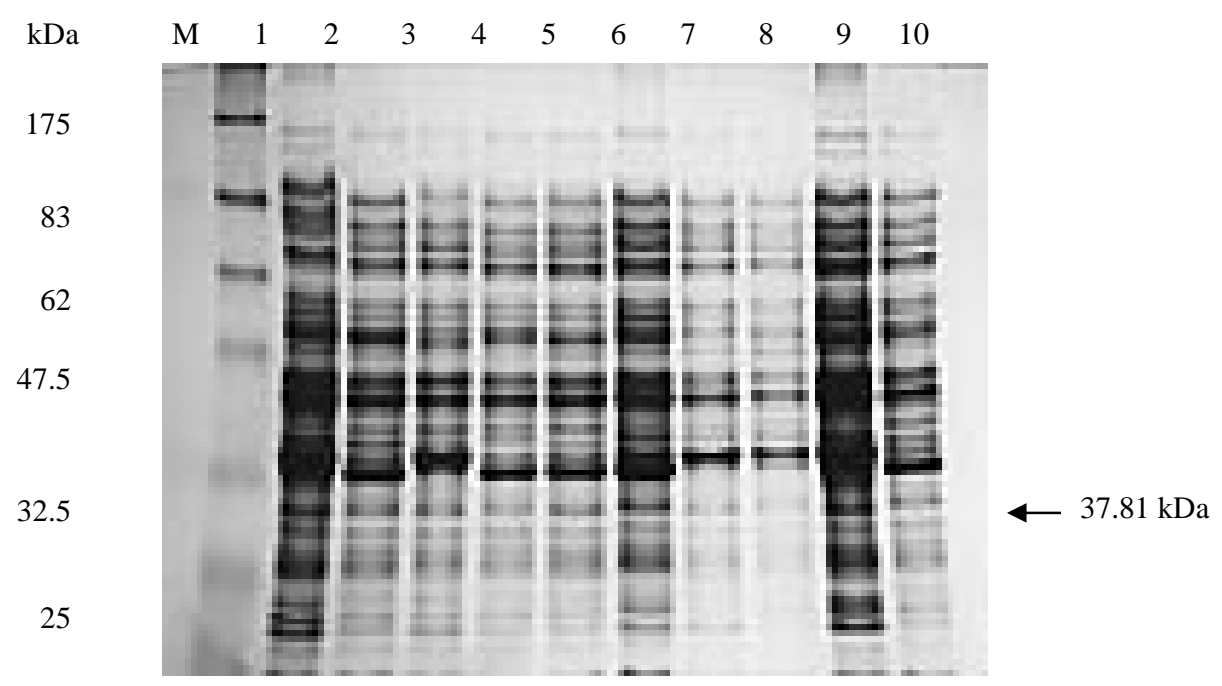

Fig. 5. Comparison of the protein profiles among Salmonella serovars. Lane 1, S. potsdam A45; Lane 2, S. risen A46; Lane 3, S. sandiego A47; Lane 4, S. senftenberg A48; Lane 5, S. taksony A49; Lane 6, S. tennesse A50; Lane 7, S. thompson A51; Lane 8, S. typhimurium L1338; Lane 9, S. virchow A53; Lane 10, S. worthington A54. Arrow indicates $37.81 \mathrm{kDa}$. M, molecular size markers.

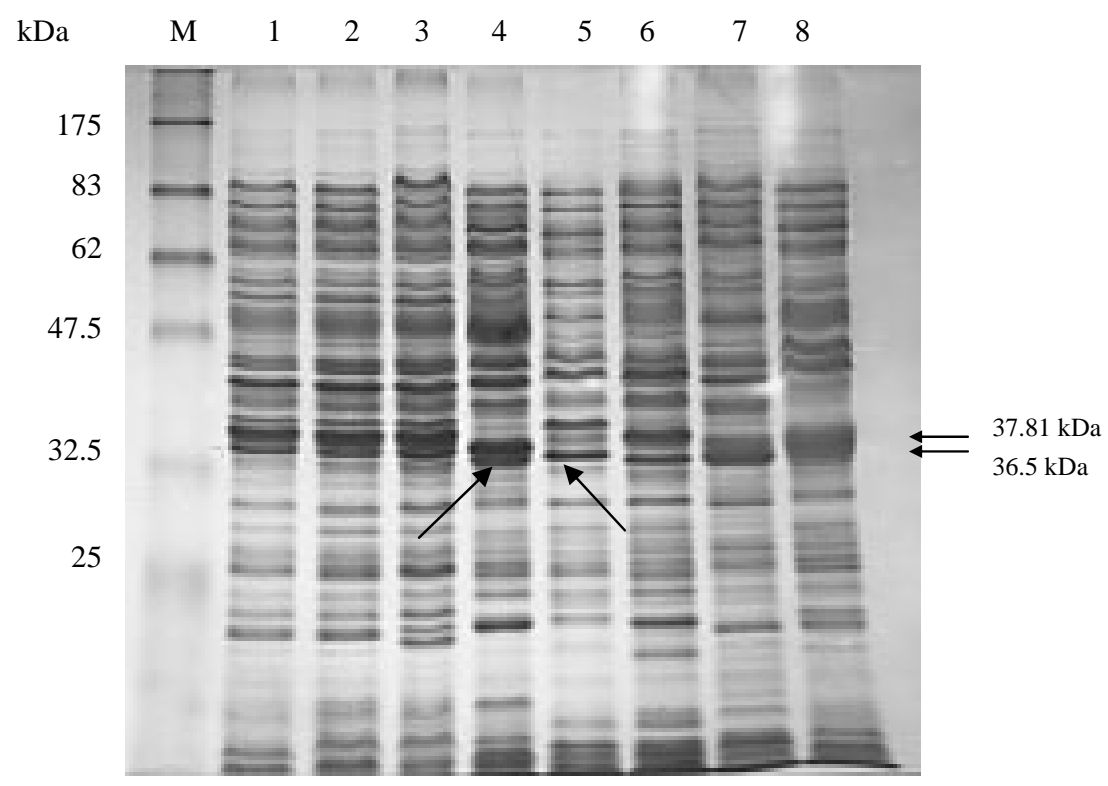

Fig. 6. Comparison of the protein profiles of three Salmonella Serovas and Enterobactria in SDS-PAGE. Lane 1, S. typhimurium L1338; Lane 2, S. cerro A12; Lane 3, S. johannesburg A28; Lane 4, E. coli v517; Lane 5, Ent. aerogenes ACLD0301; Lane 6, Klebsiella pneumoniae ACLT0201; Lane 7, Ent. cloacae ACLHa0901; Lane 8, E. coli ACLD2201. Arrows indicate $37.81 \mathrm{kDa}$ and $36.5 \mathrm{kDa}$. M, molecular size markers. 


\section{REFERENCES}

1. Erbal PJA, Barr K, Gao N, Gerwig JG, Rick PD., and Gardner KH (2003). Identification and biosynthesis of cyclic enterobacterial common antigen in Escherichia coli. Journal of Bacteriology 185: 1995-2004.

2. Hegazy SM and Adachi Y (2000). Comparison of the effect of dietary selenium, zinc, and selenium and zinc supplementation on growth and immune response between chicken groups that were inoculated with Salmonella and aflatoxin or Salmonella. Poultry Science 79: 331-335.

3. Konrad H, Smith BP, Dilling GW and John KH (1994). Production of Salmonella serogroup D (09)-specific enzymelinked immunosorbant assay antigen. American Journal of Veterinary Research 55 (12): 1647-1651.

4. Kuusi N, Nurminen M, Saxen H, Valtonen M and Makela PH (1979). Immunization with major outer membrane proteins in experimental Salmonellosis of mice. Infection and Immunity 25: 857-862.

5. Kuusi N, Nurminen M, Suxen H and Makela PH (1981). Immunization with major outer membrane protein (porin) preparations in experimental murine Salmonellosis. Infection and Immunity 34: 328-332.

6. Laemmli UK (1970). Cleavage of structural proteins during the assembly of the head of bacteriophage T4. Nature 227: 680-685.

7. Lowry OH, Rosebrough J, Farr AL and Randall RJ (1951). Protein measurement with the folin phenol reagent. Journal of Biological Chemistry 193: 265-275.

8. Matsui K and Arai T (1989). Protective immunity induced by porin in experimental mouse Salmonellosis. Microbiology and Immunology 33: 699-708.

9. McClellan M, Sanderson KE, Spieth J, Clifton SW, Latreille P, Courtney LP, Ali J, Dante M, Du F, Hou S, Layman D, Leonard S, Nguyen C, Scott K, Holmes A, Grewal N, Mulvaney E, Ryan E, Sun H, Florea L, Millers W, Stoneking T, Nhan M, Waterston R and Wilson KR (2001). Complete genome sequence of Salmonella enterica serovar typhimurium LT2. Nature 413: 852-856.

10. Meier U and Mayer H (1985). Genetic location of genes encoding enterobacterial common antigen. Journal of Bacteriology 163: 756-762.

11. Mitz H, Hellman E and Staak C (1981). Immune response and resistance to infection of calves following oral immunization against $S$. typhimurium with an inactivated vaccine. Zentralbl Veterinary Medicine (B) 28: 759-766.

12. Muthukkumar S and Muthukkaruppan VR (1993). Mechanism of protective immunity induced by porin lipopolysaccharide against murine Salmonellosis. Infection and Immunity 61: 3017-3025.

13. Nakamura A, Ota Y, Mizukami A, Ito T, Ngwai YB and Adachi Y (2002). Evaluation of aviguard, a commercial competitive exclusion product for efficacy and after effect on the antibody response of chickes of Sallmonella. Poultry Science 81: 1653-1660.

14. Nakajima S (1999). Studies on the outer membrane proteins of Salmonella Typhimurium, S. Enteritidis and S. Dublin which induce the strong humoral antibodies to the Salmonellae. Master of Science Thesis. Animal Health Laboratory, School of Agriculture, Ibaraki University.

15. Ramos F, Prieto AI, Beuzon CR, Holden DW and Casadesus J (2003). Role of Salmonella enterica enterobacterial common antigen in bile resistance and virulence. Journal of Bacteriology 185: 5328-5332.

16. Ritchie C, Foster G, Gunn G, Pearce M, Mather H (2001). Salmonella typhimurium DT170 in cattle. Veterinary Record 149: 631-634.

17. Singh SP, Sing SR, Williams YU, Jones L and Abdullah T (1995). Antigenic Determinants of the OmpC porin from Salmonella typhimurium. Infection and Immunity 63: 4600- 4605.

18. Singh SP, Upshaw Y, Abdullah T, Singh SR and Klebba PE (1992). Structural relatedness of enteric bacterial porins assessed with monoclonal antibodies to Salmonella typhimurium OmpD and OmpC. Journal of Bacteriology 174: 19651973.

19. Tabaraie B, Sharma BK, Sharma PR, Sehgal NR, Ganguly NK (1994). Evaluation of Salmonella porins as a broad spectrum vaccine candidate. Microbiology and Immunology 38: 553-559.

20. Udhayakumar V and Muthukkaruppan VR (1987). Protective immunity induced by outer membrane proteins of Salmonella typhimurium in mice. Infection and Immunity 55: 816-821.

21. Veiling J, Barkema HW, Vander J, Van Zijderveld F and Verhoeff J (2002). Herd level diagnosis for Salmonella enterica subsp. enterica serovar Dublin infection in bovine dairy herds. Preventive Veterinary Medicine 14: 31-42. 